\title{
Trzy baśnie braci Grimm z oryginalnego wydania Kinder- und Hausmärchen. Pierwszy przekład na język polski w kontekście badań nad biografią i wkładem informatorów w powstanie zbioru
}

\section{Abstrakt:}

Autorka artykułu prezentuje trzy baśnie braci Grimm - Herr Fix und Fertig [Pan Szast-Prast], Die wunderliche Gasterei [Dziwaczna uczta] i Die lange Nase [Długi nos] - z pierwszego wydania zbioru Kinder- und Hausmärchen [Baśni dla dzieci i dla domu] (1812-1815), które zostały wycofane z kolejnych edycji i z tego powodu nie były jeszcze tłumaczone na język polski. Teksty przekładów w wykonaniu autorki artykułu każdorazowo poprzedza wprowadzenie uwzględniające biografię i charakterystykę postaci bajarzy. Jest to zgodne z nurtem badań nad informatorami baśni braci Grimm przedstawionym pokrótce we wprowadzeniu do artykułu.

Słowa kluczowe:

baśń, baśnie braci Grimm, Jakub Grimm, Kinder- und Hausmärchen [Baśnie dla dzieci i dla domu], przekład, Wilhelm Grimm

Three Tales by the Grimm Brothers from the Original Edition of Kinder- und Hausmärchen: The First Polish Translation in the Context of the Research on the Informers' Biographies and Their Contribution to the Formation of the Collection

\section{Abstract:}

The author of the article presents three tales by the Grimm brothers - Herr Fix und Fertig [Herr Fix-It-Up], Die wunderliche Gasterei [The Strange Feast], and Die lange Nase [The Long Nose] - from the original edition of the Kinder- und Hausmärchen [Children's and Household Tales] collection (1812-1815), which were removed from the subsequent editions and thus were not translated into Polish yet. The texts of

* Eliza Pieciul-Karmińska - dr hab., profesor w Instytucie Lingwistyki Stosowanej Wydziału Neofilologii na Uniwersytecie im. Adama Mickiewicza w Poznaniu. Jej zainteresowania naukowe obejmują badania nad przekładem literatury dziecięcej oraz recepcję baśni braci Grimm. Kontakt: eliza.karminska@amu.edu.pl. 
the tales, translated by the author of the paper, are each time preceded by an introduction that considers the biographies and characteristics of the storytellers. This is in accordance with the trend in the research on the Grimms' informers, summarised in the article's introduction.

Keywords:

fairy tale, Grimms' folk and fairy tales, Jacob Grimm, Kinder- und Hausmärchen [Children's and Household Tales], translation, Wilhelm Grimm

\section{Wprowadzenie}

W ydaje się niemożliwe, by czytelnicy w Polsce nie znali jeszcze jakiejś baśni braci Grimm, a jednak istnieje prawie czterdzieści tekstów opracowanych przez Jakuba i Wilhelma, które nie zostały dotąd przetłumaczone na nasz język ${ }^{1}$. Są to baśnie, które nie trafiły do ostatniego, siódmego wydania zbioru Kinder- und Hausmärchen (1812-1815/1857)², a to właśnie owa ostateczna edycja (tzw. Ausgabe letzter Hand) jest podstawą wszystkich polskojęzycznych przekładów (Pieciul-Karmińska, 2019a), w tym zwłaszcza trzech tłumaczeń „wielkiego wydania"3 (Grimm, Grimm, 1857/1896, 1857/1982, 1857/2010a). W niniejszym tekście prezentuję trzy baśnie braci Grimm - Herr Fix und Fertig [Pan Szast-Prast], Die wunderliche Gasterei [Dziwaczna uczta] i Die lange Nase [Długi nos] - w tłumaczeniu na język polski. Teksty te pochodzą z pierwszego wydania zbioru (Grimm, Grimm, 1812a, 1815a) i są częścią planowanego przeze mnie przekładu wszystkich 156 baśni zamieszczonych w tej edycji (Pieciul-Karmińska, 2016).

\section{Wstęp do badań nad informatorami braci Grimm}

Do publikacji wybrałam trzy wymienione wyżej baśnie nie tylko dlatego, że są nieznane polskim czytelnikom, lecz także ze względu na informatorów, czyli

1 Listę nieprzetłumaczonych na język polski baśni oraz swoistość pierwszego wydania opisałam w artykule O konieczności polskiego przekładu pierwszego wydania Baśni dla dzieci i dla domu braci Grimm z lat 1812 i 1815 (Pieciul-Karmińska, 2016).

2 W większości były one obecne jedynie w wydaniu premierowym $\mathrm{z}$ lat $1812-1815$ - od wydania drugiego z roku 1819 zostały zastąpione innymi fabułami.

3 „Wielkie wydanie” (niem. Große Ausgabe) to nazwa pełnego zbioru baśni, której używa się dla odróżnienia od „małego wydania” (niem. Kleine Ausgabe), czyli wyboru pięćdziesięciu baśni przeznaczonych dla dzieci, opublikowanych po raz pierwszy w roku 1825 przez Wilhelma Grimma. 
osoby, które przekazały te fabuły braciom Grimm. Uważam bowiem, że identyfikacja owych informatorów jest kluczowa dla pełnego zrozumienia treści tych opowieści.

Co istotne, w baśniach z pierwszego wydania Kinder- und Hausmärchen można rozpoznać styl, ulubione sformułowania, pochodzenie geograficzne, przynależność konfesyjną i wiele innych śladów pozostawionych przez poszczególnych informatorów. Ślady te - w wyniku prac redakcyjnych Wilhelma Grimma - w kolejnych edycjach uległy unifikacji. Badania identyfikujące informatorów oraz ich wkład w powstanie zbioru baśni przynoszą wiele przełomowych i zaskakujących odkryć oraz przyczyniają się do prawdziwego renesansu tych dociekań w ojczyźnie braci Grimm. Jack Zipes (2002) określa studia niemieckojęzyczne w tym zakresie mianem „podejścia historyczno-filologicznego" 4 (s. xii), akcentując ich analityczny charakter, który - jego zdaniem - nie pozwala na szersze spojrzenie typowe dla badań anglosaskich (s. xiv). W obliczu bardzo owocnych badań prowadzonych w ostatnich latach w Niemczech opinia ta wydaje się jednak nazbyt krytyczna i uproszczona.

Dlaczego studia nad informatorami Jakuba i Wilhelma są tak ważne? Jak wiadomo, Grimmowie czerpali z rozmaitych zasobów. Wiele baśni wywodzi się wprost ze źródeł pisanych, co starannie wykazał Heinz Rölleke (1998) w synoptycznym zestawieniu tekstów. Z kolei baśnie przekazywane przez informatorów zwykle oznaczane były wskazaniem jedynie pochodzenia geograficznego (Martus, 2013, s. 209) - np. „z Hesji”, „z Bawarii” (aczkolwiek w osobistych notatkach Grimmowie zaznaczali autorstwo poszczególnych fabuł - Rölleke, 1986). Nawet uhonorowanie Dorothei Viehmann w przedmowie oraz na portrecie autorstwa Ludwiga Emila Grimma, znajdującym się na frontyspisie drugiego wydania zbioru, nie zmienia sytuacji, gdyż Grimmowie nie oznaczyli baśni, które opowiedziała im słynna „chłopka z Zwehrn” (Grimm, Grimm, 1812-1815/1819, s. xi).

Badacze wiedzieli od dawna, że dużą część baśni dostarczyło Grimmom około pięćdziesięciu osób, znanych w większości z imienia i nazwiska. Jednak dopiero Albert Schindehütte (1991) za sprawą edycji sześciu baśni przekazanych Grimmom przez Johanna Friedricha Krausego wytyczył nową perspektywę badań, które pozwalają odpowiedzieć na wiele nierozstrzygniętych dotąd pytań. Schindehütte wskazał bowiem na istotne związki między pochodzeniem i wykształceniem informatorów a postacią przekazanych fabuł ${ }^{5}$. Często

Jeśli nie podano inaczej, wszystkie tłumaczenia autorki artykułu - Elizy Pieciul-Karmińskiej. W tym kontekście istotne jest np. uwzględnienie francuskiego pochodzenia informatorów i możliwy - pośredni - wpływ takich autorów jak Charles Perrault czy Madame d'Aulnoy (Rölleke, 2004, s. 16 i nast.). 
to właśnie elementy biograficzne pozwalają uzupełnić brakujące luki w wiedzy o baśniach.

Najwybitniejszym przedstawicielem nurtu biograficznego jest zasłużony badacz baśni Heinz Rölleke, który kontynuując pomysł Schindehüttego, regularnie publikuje artykuły ukazujące związki między poszczególnymi baśniami a ich informatorami. Ukoronowaniem tych badań jest dzieło wydane wspólnie z Schindehüttem, zatytułowane Es war einmal... Die wahren Märchen der Brüder Grimm und wer sie ihnen erzählte [Dawno, dawno temu... Prawdziwe baśnie braci Grimm i kto je im opowiedział] (Rölleke, Schindehütte, 2011). Baśnie są tam pogrupowane i analizowane według klucza biograficznego poszczególnych informatorów, przy czym są to teksty zaczerpnięte wyłącznie z wydania pierwszego (Grimm, Grimm, 1812a, 1815a). Kolejne edycje zbioru nie pozwoliłyby na taką analizę, gdyż już od wydania drugiego (Grimm, Grimm, 1812-1815/1819) widoczne są efekty pracy Wilhelma, który podjął się stylistycznego ujednolicenia zbioru i zniwelował m.in. charakterystyczne elementy idiolektu poszczególnych informatorów (Pieciul-Karmińska, 2013, s. 107 i nast.). Co ciekawe, tylko baśnie przekazane w dialektach (np. O rybaku i jego żonie, O drzewie jałowca) nie zostały poddane redakcji i aż do siódmego wydania (Grimm, Grimm, 1812-1815/1857) przetrwały w prawie niezmienionym kształcie.

Warto dodać, że badania nad udziałem informatorów w „narodzinach” i ostatecznym kształcie baśni ciągle przynoszą nowe odkrycia. Najbardziej spektakularnym dokonaniem w tym zakresie było skorygowanie pomyłki najstarszego syna Wilhelma - Hermanna Grimma, który baśnie opowiedziane przez Marię Hassenpflug, młodą przyjaciółkę Grimmów o hugenockich korzeniach, przypisał „starej Marii” - piastunce swej matki Dorothei Wild - i tym samym ugruntował mit, iż większość baśni opowiedziały braciom stare wieśniaczki. Pomyłka Hermanna przez lata obciążała badania nad baśniami, gdyż sugerowała istnienie mitycznej ludowej bajarki - tej samej rangi co Dorothea Viehmann. Hermann Grimm w swych wspomnieniach podkreślał expressis verbis, że każdemu z dwóch tomów baśni patronuje wiejska bajarka - nad tomem pierwszym czuwała zatem „stara Maria”, a nad tomem drugim „pani Viehmannowa ze wsi Zwehrn”. Pisze on wręcz: „[Pani Viehmannowa] uczyniła dla drugiej części to, co stara Maria zrobiła dla pierwszej" (Grimm, 1895/1956, s. 25). Dopiero Rölleke (1975) dowiódł, że informatorka, która przekazała fabuły tak znanych baśni jak Czerwony Kapturek, Śpiaca Królewna, Śnieżka, Braciszek i siostrzyczka, to nie „stara”, lecz „młoda” Maria, bliska przyjaciółka i rówieśniczka Jakuba i Wilhelma.

Istotnych odkryć dokonuje obecnie również Holger Ehrhardt z Katedry Badań nad Spuścizną Braci Grimm na Uniwersytecie w Kassel - mieście, 
w którym Grimmowie spędzili większość życia i gdzie opublikowali pierwsze dwa wydania baśni. Dzięki analizie wpisów w księgach parafialnych, listów z epoki oraz prywatnych zapisków udało mu się ustalić personalia kobiety, która opowiedziała braciom Kopciuszka i Złotego ptaka (Ehrhardt, 2016). To niemałe osiągnięcie, zważywszy na to, że nawet sami Grimmowie nie znali jej nazwiska i określali ją mianem „bajarki z Marburga”. Nigdy nie poznali jej osobiście, gdyż - jak przypuszczano - starsza kobieta nie chciała się spotykać z młodym Wilhelmem, a poza tym nie rozumiała, dlaczego miałaby opowiadać wykształconemu panu jakieś „dziecinne bajeczki”. Grimmowie wysłali więc do niej znajomą z dwójką małych dzieci. Im właśnie Elisabeth Schellenberg - bo tak nazywała się bajarka - opowiedziała obydwie słynne baśnie ${ }^{6}$. Z kolei w 2018 roku Ehrhardt (s. 216 i nast.) zidentyfikował autorkę baśni Mysikrólik Annę Margarethę Hahn.

Właśnie w kontekście badań nad informatorami chciałabym przedstawić poniżej trzy nietłumaczone dotąd baśnie ${ }^{7} \mathrm{z}$ pierwszego wydania zbioru, poprzedzając każdą krótkim wstępem biograficznym.

\section{Pan Szast-Prast i Johann Friedrich Krause ${ }^{8}$}

Herr Fix und Fertig Jakuba i Wilhelma Grimmów (1812c) należy do wspomnianej wyżej grupy prawie czterdziestu baśni obecnych jedynie w pierwszym wydaniu zbioru Kinder- und Hausmärchen. Pan Szast-Prast - tak brzmi tytuł tej opowieści w moim przekładzie - znalazł się w pierwszym wydaniu pod numerem 16, a od wydania drugiego (Grimm, Grimm, 1812-1815/1819) zastąpiony został baśnią Trzy wężowe listki.

Opowieść została przekazana braciom przez Johanna Friedricha Krausego (1747-1828), wysłużonego żołnierza, wachmistrza dragonów, który po wieloletniej służbie zmuszony był opuścić szeregi wojska z powodu przetoki

6 Ehrhardt (2016) ustalił również, iż kobieta nie chciała się ujawnić prawdopodobnie dlatego, że wstydziła się swojej sytuacji życiowej: pochodziła bowiem z nieprawego łoża, a starość spędzała w przytułku (s. 30 i nast.).

7 Owe trzy baśnie ukazały się już w czasopismach nieobjętych recenzją naukową. Baśń Pan Szast-Prast opublikowana została w periodyku Czas Literatury (Grimm, Grimm, 1812/2019c), a baśnie Dziwaczna uczta i Długi nos - w internetowym wydaniu kwartalnika Przekrój (Grimm, Grimm, 1812/2019b, 1815/2019a).

8 O wachmistrzu Krausem i współczesnych badaniach nad tym informatorem pisałam więcej w popularyzatorskim artykule na łamach czasopisma Czas Literatury (Pieciul-Karmińska, 2019c). 
w biodrze uniemożliwiającej mu jazdę konną. Krause opowiedział Grimmom w sumie sześć baśni, wszystkie o wyraźnie autobiograficznym charakterze. Odnaleźć w nich można wiele nawiązań zarówno do żołnierskiej przeszłości wachmistrza, jak i do smutnej rzeczywistości, która stała się jego udziałem po opuszczeniu służby.

W tych fabułach odnajdziemy przede wszystkim postaci wysłużonych żołnierzy, ale także stare i niepotrzebne już nikomu zwierzęta. Dobrym przykładem jest baśń Stary Sułtan - opowieść o psie, który po latach wiernej służby ma zostać zastrzelony, bo „zestarzał się, stracił wszystkie zęby i nie był już groźny" (Grimm, Grimm, 1857/2010e, s. 250). Ale ani żołnierze z opowieści Krausego, ani pies Sułtan nie poddają się, lecz walczą o swoje życie i lepszą przyszłość. Dzięki temu wychodzą cało z opresji - przy czym stary pies wraca do łask podstępem: z pomocą przyjaciela, wilka, finguje porwanie dziecka gospodarzy, które potem „bohatersko” ratuje z kłów dzikiego zwierza.

Na tym tle baśń Pan Szast-Prast jest opowieścią szczególną, gdyż pozbawioną goryczy i resentymentu. Tytułowy bohater odchodzi ze służby wraz z zakończeniem wojny, a wojaczkę porzuca dobrowolnie, bo „nie było już nic więcej do roboty niż to samo każdego dnia” (Grimm, Grimm, 1812c, s. 58). Jego marzeniem jest służba u wielkiego pana, gdzie nosi się przetykane złotem szaty i gdzie wciąż jest coś zajmującego do roboty. Wszystko, co Szast-Prast sobie postanowi, spełnia się w mig - wskazuje na to także jego nazwisko. Niemiecka fraza fix und fertig oznacza tu bowiem umiejętność szybkiego i skutecznego działania: „szast-prast i gotowe”. Dlatego główny bohater od razu spotyka wymarzonego „wielkiego pana”, który widząc jego zmyślność, bez wahania przyjmuje go na służbę. Natychmiast powierza mu też odpowiedzialne zadanie zdobycia najpiękniejszej księżniczki na świecie, której na imię - nomen omen - Nomini. Pan Szast-Prast żwawo zabiera się do dzieła, a ponieważ jest rzutkim organizatorem - „Dajcie mi tylko powóz zaprzężony w szóstkę koni oraz woźnicę, hajduków, laufrów, lokajów, kucharza i cały dwór..." (s. 59), wszystkie decyzje, które podejmuje w drodze, okazują się trafne i niezbędne do wypełnienia powierzonej misji. I tak zwierzęta, które pan Szast-Prast po trzykroć ratuje w drodze, pomagają mu w wykonaniu trzech - zdawałoby się - niewykonalnych zadań, a wszystko oczywiście dzieje się zgodnie z logiką baśni, w której każdy dobry uczynek zostaje nagrodzony.

Ważne jest przy tym, że Szast-Prast, udając wielkiego pana i takoż będąc traktowanym (użycie słowa „pan” w tytule nie jest przypadkowe), nigdy nie wychodzi z roli sługi. Nawet nie przyjdzie mu do głowy, by księżniczkę zdobyć dla siebie. Przywozi ją do swojego pana, za co zostaje nagrodzony stanowiskiem „pierwszego ministra”. Wymowna jest przy tym formuła kończąca baśń, 
w której narrator wraca do realiów zwykłego życia: „Wielu z towarzystwa, gdzie opowiadano tę historię, zapragnęło być na tym weselu. Jedna chciała zostać pokojową, druga garderobianą, z kolei trzeci chciał zostać kamerdynerem, a inny kucharzem itd." (Grimm, Grimm, 1812c, s. 63).

Również listy wachmistrza Krausego, w których przekazywał on braciom Grimm swoje sowizdrzalskie opowieści, są istotne dla badań nad baśniami. Wynika z nich, że autor nie był bynajmniej nieokrzesanym czy niewykształconym żołnierzem. Jego język jest malowniczy, wyszukany i pełen nawiązań do dzieł literackich czy Biblii. Ta twórczość epistolarna przeszła do legendy także $\mathrm{z}$ innego powodu - w nawiązaniu do każdej przekazanej baśni, po wymianie uprzejmości i wytwornych zapewnieniach o szacunku i przywiązaniu, Krause wyprasza u „pana Wilhelma” parę używanych spodni. A robi to przykładowo w takich słowach: „Myślę codziennie o Panach, rano i wieczorem. Gdy wkładam ubranie i gdy je zdejmuję. Jednakowoż moje stare spodnie już się podarły, a ja biedak całą zimę chorowałem i ciągle jeszcze słabuję" (Schindehütte, 1991, s. 119). Mężczyźni nosili zapewne ten sam rozmiar, a prośby o znoszoną garderobę zdradzają dramatyczną sytuację życiową wachmistrza, który kiedyś żywił wielkie ambicje, był autorytetem dla podwładnych, a na starość przyszło mu żebrać.

\section{Pan Szast-Prast ${ }^{9}$}

Szast-Prast długi czas był żołnierzem, ponieważ jednak wojna dobiegła końca i nie było już nic więcej do roboty niż to samo każdego dnia, pożegnał się i postanowił zostać lokajem u wielkiego pana. Bo tam są przecież ubrania przetykane złotem, dużo do zrobienia i ciągle coś nowego. Tak więc wyruszył w drogę i dotarł do pewnego dworu. Zobaczył tam pana, który spacerował w ogrodzie. Szast-Prast, nie namyślając się długo, żwawo podszedł do niego i powiedział:

- Szukam służby u wielkiego pana i gdyby Wasza Wysokość sam nim był, toby mi się najbardziej podobało. Wszystko umiem i wiem, co się należy, w ogóle, w szczególe i wedle rozkazu.

A pan odpowiedział mu:

- Dobrze, mój synu, niech tak będzie, ale wpierw zgadnij, na co mam właśnie ochotę.

9 Baśń Herr Fix und Fertig, nr 16 w I tomie oryginalnego wydania Kinder- und Hausmärchen (Grimm, Grimm, 1812c), w przekładzie autorki artykułu - Elizy Pieciul-Karmińskiej. 
Szast-Prast bez słowa odwrócił się, ruszył spiesznie do dworu, a po chwili wrócił z fajką i tabaką.

- Dobrze, mój synu. Jesteś moim sługą i teraz nakazuję, byś sprowadził mi księżniczkę Nomini. Jest najpiękniejsza na świecie i chcę ją mieć za żonę.

- A zatem do dzieła! - odpowiedział Szast Prast. - To dla mnie drobnostka. Już niedługo Wasza Wysokość ją dostanie. Dajcie mi tylko powóz zaprzężony w szóstkę koni oraz woźnicę, hajduków, laufrów, lokajów, kucharza i cały dwór, a mnie samemu książęce ubrania, a każdy niech słucha moich rozkazów.

No i pojechali, a pan służący siedział w powozie, i zmierzali do królewskiego dworu, gdzie mieszkała owa piękna księżniczka. Gdy droga się skończyła, wjechali na pole i wkrótce dotarli do wielkiego lasu. Było tam wiele tysięcy ptaków, śpiewających okrutnie głośno, aż po krańce błękitnego nieba.

- Stać, stać! - zawołał Szast-Prast. - Nie płoszyć ptaków! One chwalą swojego Stwórcę i kiedyś zechcą mi się przysłużyć. Zawracamy w lewo!

Woźnica musiał więc zawrócić i objechać las dookoła. Nie minęło wiele czasu, gdy dotarli do wielkiego pola, gdzie siedziało z tysiąc milionów kruków, które wrzeszczały na całe gardło, domagając się jedzenia.

- Stać, stać! - zawołał Szast-Prast. - Odwiążcie jednego z koni na przedzie, zaprowadźcie go na pole i tam zadźgajcie. Trzeba nakarmić kruki, żeby przeze mnie nie cierpiały głodu.

Gdy kruki się nasyciły, ruszyli w dalszą podróż i w końcu dotarli do wody. A tam była ryba, która skarżyła się żałośnie:

- Na Boga! Nie mam co jeść w tym stęchłym bagnie, wsadźcie mnie do wartkiej wody, odpłacę się wam kiedyś!

I jeszcze nie skończyła mówić, gdy Szast-Prast już wołał:

- Stać, stać! Kucharzu, weź ją do fartucha, a ty, woźnico, jedź do wartkiej wody.

I Szast-Prast sam wysiadł, i wypuścił rybę, która z radości aż biła ogonem w wodę.

- Teraz pogońcie konie, żebyśmy dojechali na miejsce przed nocą - powiedział pan Szast-Prast.

Gdy dotarł do królewskiej rezydencji, ruszył prosto do najlepszej gospody. Karczmarz oraz wszyscy jego ludzie wyszli i witali go wylewnie, bo myśleli, że oto przybył jakiś obcy król, a to przecież był tylko pan sługa. Szast-Prast natomiast od razu kazał się zaanonsować na królewskim dworze, a tam robił wszystko, żeby się przypodobać, i zaczął starania o rękę księżniczki.

- Mój synu - powiedział król - odrzuciliśmy już wielu takich zalotników, bo żaden nie potrafił uczynić tego, co mu zostało nakazane, by dostać moją córkę. 
- Wybornie - powiedział Szast-Prast. - Niech Wasza Wysokość nakażą mi coś porządnego.

- Kazałem wysiać kwartę maku. Jeśli potrafisz przynieść mi ten mak z powrotem, ale tak, by nie brakowało ani ziarenka, będziesz mógł zabrać księżniczkę do twojego pana.

- Ho, ho! - pomyślał Szast-Prast. - To dla mnie drobnostka.

Po czym wziął miarkę, worek i śnieżnobiałe obrusy, wyszedł z zamku, a te ostatnie rozłożył obok obsianego makiem pola. Nie minęło wiele czasu, a przyleciały ptaki, które wtedy w lesie mogły śpiewać bez przeszkód, i wyzbierały nasiona, ziarnko po ziarnku, i zaniosły je na białe obrusy. Gdy wszystko już wyzbierały, Szast-Prast zsypał to razem do worka, wziął miarkę pod pachę, poszedł do króla i odmierzył mu jego wysiane nasiona, myśląc przy tym, że księżniczka jest już jego, ale spudłował.

- Jeszcze jedno, mój synu - powiedział król. - Moja córka zgubiła kiedyś złoty pierścień. Zanim będziesz mógł zabrać królewnę, musisz mi ten pierścień przynieść.

Szast-Prast nie martwił się zbytnio:

- Niech Wasza Wysokość pokażą mi tylko wodę i most, gdzie zgubiono pierścień, a wkrótce go odzyskam.

Kiedy zaprowadzono go nad wodę, spojrzał w dół, a po chwili podpłynęła tam owa ryba, którą podczas podróży wypuścił do rzeki. Ryba wystawiła głowę i powiedziała:

- Poczekaj kilka chwil, zejdę głębiej, bo wieloryb ma ten pierścień pod swoją płetwą, ale ja go wydobędę.

I niedługo potem wróciła i wyrzuciła pierścień na brzeg. Szast-Prast zaniósł go do króla, ale ten powiedział:

- Zostało jeszcze jedno zadanie. W lesie jest jednorożec, który narobił już wiele szkód. Jeśli potrafisz go zabić, to nic już więcej nie będziesz musiał robić.

Szast-Prast i o to zbytnio się nie martwił. Od razu ruszył prosto do lasu. A tam były kruki, które kiedyś nakarmił, i powiedziały do niego:

- Poczekaj chwilę, bo teraz jednorożec śpi, ale nie leży na ślepym boku ${ }^{10}$. Gdy się obróci, wówczas wydziobiemy mu to jedno dobre oko, które ma. Kiedy

${ }_{10}$ W oryginale mowa jest o scheele Seite, co w dialekcie heskim oznacza 'ślepy bok', czyli bok, na którym zwierzę ma chore, niewidzące oko. W baśni jednorożec leży początkowo na boku ze zdrowym okiem, chroniąc je w ten sposób, więc kruki nie mogą go jeszcze zaatakować i oślepić. Być może taka wersja związana jest z jakąś znaną w okolicy legendą o jednookim jednorożcu, gdyż w tekście „to jedno dobre oko, które [zwierzę] ma”, traktowane jest jako oczywisty punkt wyjścia. 
oślepnie i w szale będzie wpadał na drzewa, z pewnością wbije w któreś swój róg i wtedy bez trudu go zabijesz.

Wkrótce zwierzę przewróciło się we śnie i położyło na drugim boku. Wtedy kruki sfrunęły z drzewa i wydziobały mu zdrowe oko. Gdy jednorożec poczuł ból, skoczył na równe nogi i zaczął biegać po lesie jak oszalały, ale szybko wbił się rogiem w gruby dąb. Wtedy doskoczył do niego Szast-Prast, odrąbał mu głowę i zaniósł ją królowi. Ten nie mógł już dłużej odmawiać swojej córki i oddał ją panu Szast-Prast, który wsiadł z nią do powozu i z całym orszakiem, z jakim przybył, powrócił do swojego pana i przywiózł mu piękną księżniczkę. Powitano go tam przychylnie i wyprawiono wspaniałe wesele, a Szast-Prast został pierwszym ministrem.

Wielu $\mathrm{z}$ towarzystwa, gdzie opowiadano tę historię, zapragnęło być na tym weselu. Jedna chciała zostać pokojową, druga garderobianą, z kolei trzeci chciał zostać kamerdynerem, a inny kucharzem itd.

\section{Dziwaczna uczta i Amalie Hassenpflug ${ }^{11}$}

Baśń braci Grimm (1812b) pt. Die wunderliche Gasterei, czyli Dziwaczna uczta, to kolejna opowieść, która nie trafiła do ostatniego wydania zbioru Kinderund Hausmärchen z roku 1857, była więc dotąd nieznana polskim czytelnikom. Od trzeciego wydania (Grimm, Grimm, 1812-1815/1837) zastąpiona została baśnią Frau Trude ${ }^{12}$, opowieścią o niegrzecznej dziewczynce, „upartej i wścibskiej" (Grimm, Grimm, 1857/2010d, s. 224), która mimo surowego zakazu rodziców poszła w odwiedziny do demonicznej wiedźmy i zginęła tam marnie: dziewczynka zamieniona w kłodę drewna musiała spłonąć w piecu wiedźmy. Ale „jakże [...] mogło się jej dobrze wieść” - pyta narrator baśni - jeśli dziewczynka, „gdy rodzice coś jej kazali zrobić, [...] nie słuchała," (s. 224). Jest to zatem dydaktyczna opowiastka, której drastyczna fabuła - podobnie jak w przypadku Czerwonego Kapturka lub baśni O wilku i siedmiu koźlątkach - pełni funkcję ostrzegawczą.

Czy poprzedniczka Pani Trude, czyli baśń Dziwaczna uczta, zapisana pod numerem $43 \mathrm{w}$ pierwszym tomie zbioru, miała zbliżony charakter i przesłanie? Wprost przeciwnie. Dziwaczna uczta to całkowita odwrotność pouczającej

11 Rozszerzony, popularyzatorski tekst wprowadzenia ukazał się pierwotnie na stronie internetowej kwartalnika Przekrój (Pieciul-Karmińska, 2019b).

12 Polskie tytuły tej baśni to: Baba Truda (tłum. Z. A. Kowerska), Baba Jaga (tłum. E. Bielicka) oraz Pani Trude (tłum. E. Pieciul-Karmińska). 
przypowieści o nieposłusznym dziecku. I tym razem kluczem do pełnego zrozumienia tej baśni jest osoba informatorki, która opowiedziała braciom ową fabułę. Była to Amalie Hassenpflug (1800-1871) z zaprzyjaźnionej z Grimmami zamożnej mieszczańskiej rodziny o hugenockich korzeniach. W chwili, gdy przekazała Wilhelmowi swą opowieść, dziewczynka miała raptem dziesięć lat! Jej starsze siostry - Jeanette, a zwłaszcza Marie, przywołana już tutaj w kontekście pomyłki Hermanna Grimma dotyczącej osoby „starej Marii” - zbierały dla Grimmów fabuły baśni, natomiast ich brat Ludwig odegrał ważną rolę w życiu Jakuba i Wilhelma $\mathrm{z}$ innego powodu: ożenił się z ich jedyną siostrą Lotte. Po jej przedwczesnej śmierci w 1833 roku to właśnie niezamężna Amalie Hassenpflug pomagała Ludwigowi w prowadzeniu domu i wychowywaniu trójki dzieci (Rölleke, Schindehütte, 2011, s. 394).

Amalie od małego zdradzała zdolności literackie i przejawiała szczególną skłonność do snucia prześmiewczych, sowizdrzalskich opowieści. W tej właśnie konwencji Grimmowie, którzy znali ją niemal od urodzenia, nazywali ją żartobliwie Male, schnipp dich, czyli „Malcia, wysmarkaj się” lub „Malcia smarkula” (Rölleke, Schindehütte, 2011, s. 394). Opowiedziana przez nią Dziwaczna uczta to opowieść $\mathrm{z}$ „czarnego" repertuaru makabresek i horrorów, jakże podobna do historyjek o wampirach, trupach i odciętych głowach, którymi dzieci do dzisiaj straszą się nawzajem na koloniach po zgaszeniu światła. I tak właśnie należy ją czytać - pomimo elementów grozy jest to po prostu żartobliwa opowieść utrzymana w konwencji purnonsensu (s. 402).

Historyjka rozpoczyna się niewinnie, a dobór postaci budzić może rozbawienie. Bohaterkami opowiadania są bowiem kaszanka i zaprzyjaźniona z nią wątrobianka, którą ta pierwsza zaprasza do siebie na tytułową „ucztę”. Kaszanka w języku niemieckim nosi wyraziste miano „krwawej kiszki” (niem. Blutwurst), więc zgodnie ze swym imieniem ma mordercze zamiary, czego naiwna wątrobianka zupełnie nie podejrzewa. Fabuła baśni jest groteskowa i wyraźnie parodystyczna, co podkreślał sam Wilhelm Grimm w liście do brata Ferdynanda, gdy pisał o „małej [Malci]”, która nie tylko ma rozum, lecz także wyraźny talent do karykaturalnych, prześmiewczych fabuł (Rölleke, Schindehütte, 2011, s. 394).

Godny uwagi jest tu również zaskakujący wtręt narratora odnoszący się do tajemniczego przybysza, który zjawia się niespodziewanie w kuchni, by przestrzec bezbronną wątrobiankę: „I nagle do środka wszedł ktoś - nie wiem, kto to był - i powiedział [...]”. Najwyraźniej uwaga ta pochodzi od samej Malci, która w ferworze opowieści zapomniała, albo nie zdążyła wymyślić, kto ostrzegł kaszankę, a może uznała to za nieistotny szczegół. Wilhelm Grimm odnotował w swoich zapiskach, że: „kaszanka została ostrzeżona przez [ ]” 
(Rölleke, Schindehütte, 2011, s. 42), po czym w duchu wierności „ustnej tradycji ludowej" pieczołowicie odtworzył w drukowanej, ostatecznej wersji baśni pierwszoosobową wypowiedź narratora, który sam „nie wie, kto to był”. Ciekawe, że ślady wierności „ustnej tradycji” zachowały się akurat w baśni, która nie pochodzi przecież od wiejskiej bajarki (s. 42 i nast.).

Amalie Hassenpflug opowiedziała braciom jeszcze baśnie Diabeł o trzech złotych włosach i Pan kum oraz własną wersję Trzech leśnych trolli, odmienną od tej, jaką znamy z ostatniego wydania baśni z 1857 roku.

\section{Dziwaczna uczta ${ }^{13}$}

Przez pewien czas kaszanka i wątrobianka mieszkały blisko siebie i kiedyś kaszanka zaprosiła wątrobiankę w gości. Gdy przyszła pora posiłku, wątrobianka ruszyła raźnie do kaszanki. Kiedy stanęła w drzwiach, ujrzała najrozmaitsze dziwaczne rzeczy. Na każdym stopniu schodów, których było wiele, działo się coś osobliwego - była tam miotła i szufelka, które biły się ze sobą, była też małpa $\mathrm{z}$ wielką dziurą $\mathrm{w}$ głowie i wiele podobnych rzeczy.

Wszystko to mocno zdeprymowało i przestraszyło wątrobiankę, a jednak wzięła się na odwagę i weszła do izby, gdzie serdecznie przywitała ją kaszanka. Ale kiedy zaczęła wypytać o te dziwne wydarzenia, które działy się na schodach, kaszanka udawała, że nie słyszy, albo sprawiała wrażenie, jakby nie było o czym mówić, lub mówiła o szufelce i miotle: „To na pewno była moja służąca, która plotkowała z kimś na schodach", albo też kierowała rozmowę na inny temat.

W końcu kaszanka wyszła z izby, mówiąc, że musi w kuchni przypilnować jedzenia i sprawdzić, czy wszystko porządnie przyrządzono i niczego nie wyrzucono w popiół. W tym czasie wątrobianka chodziła po izbie tam i z powrotem, bo ciągle miała w głowie te dziwaczne zdarzenia na schodach. I nagle do środka wszedł ktoś - nie wiem, kto to był - i powiedział:

- Ostrzegam cię, wątrobianko, jesteś w krwawej siedzibie zbójców, szybko stąd uciekaj, jeśli ci życie miłe.

Wątrobianka bez chwili zastanowienia przekradła się do drzwi, a potem biegła ile sił i nie zatrzymała się, aż nie znalazła się na środku ulicy. Wtedy obejrzała się i w oknie na strychu zobaczyła kaszankę, która stała tam z długim,

13 Baśń Die wunderliche Gasterei, nr 43 w I tomie oryginalnego wydania Kinder- und Hausmärchen (Grimm, Grimm, 1812b), w przekładzie autorki artykułu - Elizy Pieciul-Karmińskiej. 
długim nożem, a on błyszczał, jakby był świeżo naostrzony. I kaszanka, wygrażając nożem, krzyknęła w dół do wątrobianki:

- Gdybym cię dopadła, tobym cię zjadła!

\section{Długi nos i Dorothea Viehmann ${ }^{14}$}

Baśń Die lange Nase (Grimm, Grimm, 1815b), czyli Długi nos, także nie była dotąd znana polskim czytelnikom. Ona również należy do grupy baśni obecnych jedynie w pierwszym wydaniu zbioru Kinder- und Hausmärchen z lat 1812-1815, którego nigdy dotąd nie tłumaczono na język polski. A szkoda, bo opowiadanie o trzech wysłużonych żołnierzach, którzy „byli tak starzy, że nie mogli już nawet ugryźć budyniu” (s. 185), posiada wiele interesujących cech. To opowieść sowizdrzalska, bez wyraźnego antagonisty, bo nawet negatywna postać przebiegłej królewny budzi sympatię, a kara, która ją spotyka, jest bardziej groteskowa niż surowa. Zaskakujące jest także zakończenie baśni: król wcale nie oddaje żadnemu z żołnierzy swojej córki za żonę.

Dlaczego baśń ta została wycofana z kolejnych wydań Kinder- und Hausmärchen? Prawdopodobnie bracia Grimm nie chcieli dublować tematów. Kluczowy dla tej baśni motyw wykradanych i odzyskiwanych na nowo czarodziejskich przedmiotów obecny jest w kilku innych tekstach, zwłaszcza w znanej baśni O stoliczku-nakryj się, złotym ośle i kiju samobiju. Począwszy od drugiego wydania (Grimm, Grimm, 1812-1815/1819) miejsce Dlugiego nosa zajęła baśń Ośle ziele, w której pojawia się z kolei analogiczny motyw czarodziejskiej rośliny użytej w charakterze kary i szantażu.

Kto opowiedział braciom Grimm baśń Długi nos? Sami autorzy zbioru oznaczyli ten tekst dopiskiem „ze Zwehrn”, który jednoznacznie wskazuje na Dorotheę Viehmann, mieszkankę wsi Niederzwehren pod Kassel (obecnie dzielnica tego miasta). Dorothea Viehmann (1755-1815) to najsłynniejsza Grimmowska bajarka, która przekazała braciom około czterdziestu fabuł, z czego aż dwadzieścia obecnych jest w całości w znanym nam wydaniu z roku 1857. Są to m.in. Wierny Jan, Mądra Elżunia, Trzy piórka, Frycek i Katarzynka, Goździk, Gęsiarka, Mądra wieśniaczka, Doktor Wszechwiedzący, Żelazny piec, Biedny młynarczyk $i$ kotka, Diabeł $i$ jego babcia (Rölleke, 2012, s. 30 i nast.). Grimmowie byli przekonani, że wreszcie udało im się spotkać prawdziwą

14 Rozszerzony i bardziej popularyzatorski tekst wprowadzenia ukazał się pierwotnie na stronie internetowej kwartalnika Przekrój (Pieciul-Karmińska, 2019d). 
wiejską bajarkę - chłopkę, która swymi opowieściami uwiarygodniła ich zamiar spisywania ludowych, ustnych przekazów.

Dorothea Viehmann odwiedzała braci w ich mieszkaniu w Kassel zwykle w środy, gdy przybywała na targ, by sprzedawać wiejskie produkty przyniesione w koszu na plecach. Ukoronowaniem dnia były właśnie wizyty u braci, gdzie mogła odpocząć, a przy okazji podzielić się opowieściami, za które dostawała niewielką zapłatę. Grimmowie podejmowali ją z honorami, a Dorothea opowiadała potem znajomym, że do herbaty podawali jej prawdziwą srebrną łyżeczkę, jakby była jedną z nich. Ta srebrna łyżeczka pojawiła się nawet we wspomnianej już baśni Diabeł i jego babcia jako istotny element diabelskiej zagadki: „W Morzu Północnym leży martwy koczkodan. Dostanę z niego pieczeń. A z wieloryba żebro, to będzie ich srebrna łyżka. A stare, puste końskie kopyto, to będzie ich kielich" (Grimm, Grimm, 1857/2010a, s. 153).

Dlaczego srebrna łyżeczka była tak ważna dla bajarki? Otóż Viehmannowa wcale nie była chłopką i nie uprawiała ziemi ${ }^{15}$. Dzięki najnowszym badaniom (Ehrhardt, 2012) wiemy, że mianem wieśniaczki można ją było określić wyłącznie z powodu miejsca zamieszkania, bo do wsi Niederzwehren pod Kassel przeprowadziła się dopiero po dość późnym jak na owe czasy zamążpójściu w wieku 32 lat. Dorothea Viehmann, z domu Pierson, pochodziła z zamożnej rodziny o hugenockich korzeniach. Jej ojciec był właścicielem słynnej karczmy Knallhütte, oddalonej od Kassel o godzinę jazdy konnej. Dorothea spędziła tutaj trzy dekady: pomagała ojcu w obsłudze gości i w prowadzeniu gospody $(8 \text { i nast. })^{16}$.

W karczmie można było spotkać gości najróżniejszego autoramentu: rzemieślników, kupców, woźniców, z pewnością ciągnęli tędy także żołnierze, więc z dużym prawdopodobieństwem możemy założyć, że właśnie tutaj Dorothea Viehmann usłyszała opowieść o Długim nosie. W baśni tej pojawia się nawet gościnna gospoda, w której cudownie wzbogacony żołnierz mógł bez

15 Warzywa, które kobieta sprzedawała na targu w Kassel, zaczęła uprawiać w przydomowym ogródku stosunkowo późno, gdy musiała zdobyć dodatkowe pieniądze dla swej owdowiałej córki i jej licznych dzieci.

16 Do jej obowiązków należało też z pewnością nalewanie piwa z beczek, co uwieczniła w prześmiewczej baśni Mądra Elżunia, gdzie niezwykle plastycznie opisuje tę pozornie zwyczajną czynność. Oto tytułowa bohaterka, gdy szła po piwo do piwnicy: „[...] po drodze dzielnie klapała pokrywką dzbana, żeby czas jej się nie dłużył. Gdy była już na dole, wzięła stołeczek i postawiła przed beczką, żeby nie musiała się schylać i nie bolały jej plecy, które mogłyby się nadwyrężyć. Potem postawiła przed sobą dzbanek i odkręciła kurek. Gdy piwo lało się do środka, Elżunia nie chciała bezczynnie się w nie wpatrywać, więc spojrzała na ścianę..." (Grimm, Grimm, 1857/2010c, s. 183). I tu zaczyna się cała seria niefortunnych zdarzeń. 
problemu zapłacić za suty posiłek i „nie oszukał karczmarza ani na halerz” (Grimm, Grimm, 1815b, s. 187). W zbiorze Baśnie dla dzieci i dla domu znajdziemy wiele podobnych opowieści, w których pokrzywdzeni przez los wojacy dzięki czarom biorą odwet za swoje niedole. Zwykle zdobywają majątek, a czasami królewnę za żonę, chociaż - jak się okazuje - w opowieściach o wysłużonych żołnierzach nie jest to wcale obowiązkowy element baśniowego happy endu.

\section{Długi nos ${ }^{17}$}

Było raz trzech wysłużonych żołnierzy, którzy byli tak starzy, że nie mogli już nawet ugryźć budyniu, więc król pozbył się ich, nie dając im grosza emerytury. Wojacy nie mieli z czego żyć i pozostała im tylko wędrowna żebranina. Szli właśnie przez wielki las i nie mogli znaleźć jego końca, a gdy zapadł wieczór, dwóch położyło się spać, a trzeci musiał trzymać wartę, żeby nie rozszarpały ich dzikie zwierzęta. I gdy ci dwaj zasnęli, a jeden stał przy nich na straży, zjawił się człowieczek w czerwonym odzieniu i krzyknął:

- Kto tam?

- Dobry przyjaciel! - odpowiedział żołnierz.

- Co za dobry przyjaciel?

- Trzej wysłużeni żołnierze, którzy nie mają z czego żyć.

A wtedy człowieczek powiedział, że jeśli żołnierz podejdzie do niego, to obdaruje go prezentem, i jeżeli odpowiednio się nim posłuży, to będzie bogaty do końca swych dni. Żołnierz podszedł do człowieczka w czerwonym odzieniu, a ten podarował mu stary płaszcz. Gdy tylko żołnierz go założył, spełniało się wszystko, czego tylko sobie zażyczył. Jednak nie wolno mu było opowiedzieć o tym towarzyszom przed nastaniem dnia. Dopiero gdy zaświtało, a oni się obudzili, opowiedział im, co się wydarzyło. A potem poszli dalej i wędrowali aż do następnego wieczoru. Kiedy kładli się spać, to drugi z nich miał czuwać i stać na straży. A wtedy znowu zjawił się czerwony człowieczek i krzyknął:

- Kto tam?

- Dobry przyjaciel!

- Co za dobry przyjaciel?

- Trzej starzy wysłużeni żołnierze.

17 Baśń Die lange Nase, nr 36 w II tomie oryginalnego wydania Kinder- und Hausmärchen (Grimm, Grimm, 1815b), w przekładzie autorki artykułu - Elizy Pieciul-Karmińskiej. 
I wtedy człowieczek podarował wojakowi stary mieszek, który zawsze był pełen pieniędzy, choćby nie wiadomo, ile się ich stamtąd wyjęło. Również teraz żołnierzowi wolno było opowiedzieć o tym towarzyszom dopiero o świcie. Trzeciego dnia dalej szli przez las aż do zmroku i nocą stanął na straży trzeci żołnierz. Czerwony człowieczek przyszedł także do niego.

- Kto tam? - krzyknął.

- Dobry przyjaciel!

- Co za dobry przyjaciel?

- Trzej starzy wysłużeni żołnierze.

Wtedy czerwony człowieczek podarował mu róg, a gdy się weń zadęło, to wokół zbierały się armie wszystkich narodów. Rano, gdy każdy miał już jeden podarunek, pierwszy żołnierz założył płaszcz i zażyczył sobie, żeby nareszcie wyszli z tego lasu. I oto w mig stanęli poza nim. Zaraz poszli do gospody i kazali sobie dać jedzenia i picia, najlepszego, jakie tylko karczmarz mógł zdobyć. A gdy się z tym uporali, żołnierz z mieszkiem zapłacił za wszystko i nie oszukał karczmarza ani na halerz. A ponieważ byli już zmęczeni wędrowaniem, ten z mieszkiem powiedział do tego z płaszczem:

- Chciałbym, żebyś zażyczył sobie zamku. Pieniędzy mamy przecież dosyć i możemy żyć jak książęta.

I zaraz stanął tam zamek ze wszystkim co trzeba. A gdy tak sobie pożyli jakiś czas, żołnierz z płaszczem zażyczył sobie karety zaprzężonej w trzy siwki. Chcieli w niej pojechać do sąsiedniego królestwa i podać się tam za królewiczów. Wyruszyli więc z tak wielkim orszakiem lokajów, że to naprawdę wyglądało bardzo po książęcemu. Pojechali do króla, który miał tylko jedną jedyną księżniczkę. Gdy tylko się zapowiedzieli, to zaraz przygotowano dla nich komnaty i poproszono do stołu. I bawili się wesoło, a gdy zjedli i wypili, to zaczęli grać w karty, za czym księżniczka bardzo przepadała. Grała z tym, który miał mieszek, i wciąż wygrywała. Aż w końcu zauważyła, że mieszek ów wcale się nie opróżnia i zrozumiała, że jest zaczarowany. Wtedy powiedziała do żołnierza, że przecież tak się zgrzał od tej gry, że powinien się napić, i nalała mu wina, do którego dodała napoju nasennego. A gdy tylko się napił, to zaraz zasnął, a wtedy księżniczka zabrała jego mieszek, poszła do swojej komnaty i uszyła inny, który wyglądał tak samo. Włożyła do nowego mieszka trochę pieniędzy i położyła go na miejscu starego. Następnego ranka trzej żołnierze wyruszyli w dalszą drogę, a gdy właściciel mieszka wydał tę odrobinę pieniędzy, która tam jeszcze pozostała, i znowu do niego sięgnął, to mieszek okazał się pusty. Wtedy zakrzykną:

- Mój mieszek został zamieniony przez podstępną księżniczkę, a my staliśmy się biedakami! 
Ale kolega z czarodziejskim płaszczem powiedział:

- Niech cię o to głowa nie boli. Zaraz go odzyskam.

Od razu założył płaszcz i zażyczył sobie, by znaleźć się w komnacie księżniczki. Przeniósł się tam natychmiast i ujrzał ją, jak siedzi i liczy pieniądze, które co rusz wyciąga z mieszka. A kiedy księżniczka go zobaczyła, zaczęła wrzeszczeć, że jest u niej zbójca, a krzyczała tak głośno, że nadbiegł cały dwór, i już by go złapano, ale w ostatniej chwili żołnierz wyskoczył przez okno, gubiąc jednak płaszcz, który spadł mu z ramion. I gdy tych trzech znowu zebrało się razem, to nie mieli już nic ponad róg, a wtedy jego właściciel powiedział:

- Zaradzę temu. Rozpoczniemy wojnę.

I zadął, przywołując tak wielu huzarów i takie mnóstwo kawalerii, że nie dało się ich wszystkich zliczyć. Potem wysłał do króla posłańca z żądaniem, by oddał mieszek i płaszcz, bo jeśli nie, to z jego zamku nie zostanie kamień na kamieniu. Wtedy król zaczął namawiać córkę, by oddała skradzione skarby, zanim sprowadzą sobie na kark wielkie nieszczęście. Ale księżniczka odpowiedziała, że jeszcze spróbuje innego sposobu. I ubrała się jak uboga dziewczyna, wzięła koszyk na ramię i wyszła do obozu, by sprzedawać tam trunki, i poszła z nią jej pokojówka. Gdy dotarła do obozu, zaczęła śpiewać tak pięknie, że cała armia zbiegła się z namiotów i słuchała, a wśród nich także ten, który miał róg. Kiedy księżniczka go dostrzegła, dała znak pokojówce, która zakradła się do jego namiotu, zabrała róg i pobiegła do zamku. Potem i księżniczka wróciła do domu. I teraz miała już wszystko, a tych trzech towarzyszy musiało znowu iść na żebry.

Szli i szli, aż ten, który miał kiedyś mieszek, powiedział:

- Wiecie co, nie możemy ciągle być razem. Wy idźcie w tamtą stronę, a ja pójdę w tę.

I poszedł sam. Dotarł do lasu, a ponieważ był zmęczony, położył się pod drzewem, by trochę pospać. A gdy się obudził i spojrzał w górę, to okazało się, że spał pod piękną jabłonią, na której wisiały wspaniałe jabłka. Zgłodniały zerwał jedno i zjadł, a potem zjadł jeszcze jedno. I wtedy zaczął mu rosnąć nos. Rósł i rósł, był już tak długi, że żołnierz nie mógł wstać, a nos nadal rósł w lesie i jeszcze sześćdziesiąt mil poza las.

A jego towarzysze wędrowali tymczasem po świecie i szukali druha, bo przecież lepiej jest wędrować w towarzystwie, lecz nigdzie nie mogli go znaleźć. Nagle jeden z nich potknął się o coś i stanął na czymś miękkim - i aj! „Co to może być?” - pomyślał. A wtedy to coś drgnęło i oczom wędrowców ukazał się ogromny nos. Postanowili pójść za tym nosem i wreszcie dotarli do lasu, gdzie leżał ich towarzysz i nie mógł się ruszyć ani wstać. Koledzy wzięli więc drążek, owinęli wokół niego nos i chcieli go podnieść do góry, ale okazało się, że jest za ciężki. Szczęściem znaleźli w lesie osła, na którym położyli żołnierza, 
a długi nos nieśli przed nim na dwóch drążkach. Ale gdy przebyli kawałek drogi, zmęczyli się tak bardzo, że musieli odpocząć. I gdy tak odpoczywali, zobaczyli obok siebie drzewo, na którym wisiały piękne gruszki, a zza drzewa wyszedł człowieczek w czerwieni i powiedział do długonosego, że musi zjeść jedną z gruszek, to wtedy nos mu odpadnie. I rzeczywiście, kiedy żołnierz zjadł jedną gruszkę, to zaraz długi nos mu odpadł, a ostał mu się nie większy, niż miał poprzednio. A wtedy człowieczek powiedział:

- Nazrywaj jabłek i gruszek, wysusz je i zrób z nich proszek. Każdemu, komu dasz proszku jabłkowego, temu urośnie nos, a jeśli potem dasz mu proszku gruszkowego, temu długi nos odpadnie. Podaj się za wędrownego lekarza i najpierw daj księżniczce jabłko, a potem także proszek, a wtedy nos urośnie jej dwadzieścia razy dłuższy, ale niech cię to nie przestraszy!

Żołnierz nazbierał jabłek, poszedł na dwór królewski i podając się tam za ogrodnika ${ }^{18}$, powiedział, że ma taki rodzaj jabłek, które w ogóle nie rosną w tej okolicy. Gdy księżniczka to usłyszała, poprosiła ojca, by jej kupił kilka z tych jabłek, a król powiedział:

- Kup sobie, ile chcesz.

Kupiła więc i zjadła jedno. Tak jej smakowało, jakby przez całe swoje życie nie jadła lepszego. Zjadła więc jeszcze jedno, a gdy to się stało, lekarz wziął nogi za pas. Wtedy nos zaczął rosnąć i urósł tak wielki, że nie mogła wstać z fotela i w końcu upadła. Nos urósł na sześćdziesiąt łokci wokół stołu, na sześćdziesiąt wokół jej szafy, a potem wydobył się przez okno, wydłużył o sto łokci wokół zamku i powędrował dwadzieścia mil w kierunku miasta. Księżniczka leżała i nie mogła się ruszyć ani wstać, a żaden lekarz nie potrafił jej pomóc. Stary król kazał ogłosić, że jeśli znajdzie się jakiś przybysz, który potrafi pomóc jego córce, to dostanie za to mnóstwo pieniędzy. Stary żołnierz tylko na to czekał, zgłosił się jako doktor i powiedział:

- Jeśli taka wola Boża, to postaram się jej pomóc.

I dał jej proszku z jabłek, przez co nos zaczął rosnąć jeszcze bardziej, a wieczorem dał jej proszku z gruszek, i wtedy nos się trochę zmniejszył. Następnego dnia znowu dał jej proszku z jabłek, aby porządnie ją przestraszyć i ukarać, a wtedy nos znowu urósł i był o wiele większy niż wczoraj. W końcu powiedział:

- Najłaskawsza księżniczko, najwyraźniej kiedyś musiała pani coś ukraść. Jeśli pani tego nie odda, nie będę mógł pomóc.

18 W przekładzie starałam się utrzymać styl narracji oryginału, więc pewne sformułowania oddawałam dosłownie, by zachować charakterystyczną składnię i sposób obrazowania. Zachowałam także nieścisłości, np. gdy żołnierz ma się podać za lekarza, lecz podaje się za ogrodnika, a mimo to w narracji nazwany zostaje „doktorem”. 
- O niczym nie wiem - odpowiedziała.

A on na to:

- Tak właśnie jest, bo inaczej mój proszek już by pomógł. Jeśli pani nie odda skradzionych przedmiotów, to będzie musiała umrzeć z powodu długiego nosa.

A wtedy król powiedział:

- Oddaj mieszek, płaszcz i róg. Przecież je ukradłaś. Oddaj, bo twój nos nigdy się nie zmniejszy!

I pokojówka musiała przynieść wszystkie trzy rzeczy, a żołnierz w zamian dał księżniczce proszek z gruszek. A wtedy nos odpadł i musiało przyjść dwustu pięćdziesięciu mężczyzn, żeby porąbać go na kawałki i wynieść z zamku. A żołnierz ruszył do swych towarzyszy z mieszkiem, płaszczem i rogiem. I znowu zażyczyli sobie zamku. I pewnie wciąż jeszcze tam siedzą i spokojnie gospodarują.

\section{Podsumowanie}

Zaprezentowane tutaj trzy nietłumaczone dotąd na język polski baśnie braci Grimm to niewielka część planowanego przeze mnie przekładu całego pierwszego wydania Kinder- und Hausmärchen (Pieciul-Karmińska, 2016). Wybór akurat tych trzech baśni spośród wszystkich 156 nie jest przypadkowy, ponieważ dla pełnego ich zrozumienia istotne jest poznanie informatora. $\mathrm{Z}$ tego powodu przekłady poprzedzone zostały kontekstem biograficznym, co wpisuje się w nurt badań nad informatorami Grimmowskimi.

Podsumowując prezentację premierowego tłumaczenia wybranych baśni braci Grimm, warto wskazać jeszcze szczególne cechy przedstawionych tutaj informatorów, które mają wpływ na pełniejsze zrozumienie tych tekstów. Johann Friedrich Krause był zawsze interesującym obiektem badań, gdyż stanowił rzadki przypadek bajarza - mężczyzny ${ }^{19}$. Jednak dopiero dzięki uwzględnieniu całego kontekstu jego życia oraz twórczości wykraczającej poza sześć baśni opowiedzianych braciom Grimm ${ }^{20}$, która ujawnia staranne wykształcenie i literacką ogładę tego wysłużonego żołnierza, można badać przekazane

19 Baśnie opowiadały Jakubowi i Wilhelmowi przede wszystkim kobiety, a mężczyźni stanowili raczej wyjątek wśród informatorów. Poza Krausem wskazać można jeszcze malarza Philippa Ottona Rungego i arystokratę z Westfalii Augusta von Haxthausena.

${ }_{20}$ Mowa o wspomnianej wyżej korespondencji, a także o odkrytym niedawno zeszycie z własnoręcznymi zapiskami Krausego (tzw. Das Spinnenstubenheft), który został wydany drukiem przez Alberta Schindehüttego (1992). 
przez niego opowieści z nowej perspektywy. Również Amalie Hassenpflug, rezolutna dziewczynka z mieszczańskiego domu, znacznie odbiega od popularnych wyobrażeń o wiekowych piastunkach i wiejskich bajarkach, gdyż swoje fabuły przekazała braciom Grimm, gdy miała zaledwie dziesięć lat. I wreszcie pozornie bardzo dobrze znana Dorothea Viehmann, legendarna Grimmowska bajarka, w świetle najnowszych badań nie jest już chłopką, rdzenną mieszkanką Hesji, lecz córką zamożnego browarnika o hugenockich korzeniach.

W przedstawionych tutaj baśniach opowiedzianych przez tak różnych informatorów można się jednak doszukać pewnego podobieństwa. Wszystkie one wykazują cechy, które za sprawą prac redakcyjnych Wilhelma powoli znikały z kolejnych wydań (Pieciul-Karmińska, 2016). Te nieco sowizdrzalskie, czasem prześmiewcze fabuły, są dobrym wprowadzeniem w swoistość gatunkową i tematyczną pierwszego wydania Kinder- und Hausmärchen Jakuba i Wilhelma Grimmów z lat 1812-1815.

\section{Bibliografia}

Ehrhardt, H. (2012). Dorothea Viehmann, geb. Pierson. Herkunft, Lebensweg und Erinnerung. W: H. Ehrhardt (red.), Dorothea Viehmann (s. 8-29). Kassel: Euroregioverlag.

Ehrhardt, H. (2016). Die Marburger Märchenfrau. Oder Aufhellungen eines »nicht einmal Vermutungen erlaubenden Dunkels«. Kassel: Boxan Verlag.

Ehrhardt, H. (2018). Eine bisher unbeachtete Beiträgerin zu KHM 171. W: H. Ehrhardt (red.), Über Nachtfliegen, Zaunkönige und Meisterdiebe. Neue Beiträge zur Grimm- und Märchenforschung (s. 197-230). Kassel: Kassel University Press.

Grimm, H. (1956). Erinnerungen. W: W. Grimm, J. Grimm, Kinder- und Hausmärchen (t. 1, s. 5-28). München: Winkler. (wyd. oryg. 1895).

Grimm, W., Grimm, J. (1812a). Die Kinder- und Hausmärchen. Gesammelt durch die Brüder Grimm. Berlin: Realschulbuchhandlung.

Grimm, W., Grimm, J. (1812b). Die wunderliche Gasterei. W: Die Kinder- und Hausmärchen. Gesammelt durch die Brüder Grimm (s. 191-193). Berlin: Realschulbuchhandlung.

Grimm, W., Grimm, J. (1812c). Herr Fix und Fertig. W: Die Kinder- und Hausmärchen. Gesammelt durch die Brüder Grimm (s. 58-63). Berlin: Realschulbuchhandlung.

Grimm, W., Grimm, J. (1815a). Die Kinder- und Hausmärchen. Gesammelt durch die Brüder Grimm. Zweiter Band. Berlin: Realschulbuchhandlung.

Grimm, W., Grimm, J. (1815b). Die lange Nase. W: Die Kinder- und Hausmärchen. Gesammelt durch die Brüder Grimm. Zweiter Band (s. 185-193). Berlin: Realschulbuchhandlung. 
Grimm, W., Grimm, J. (1819). Die Kinder- und Hausmärchen. Gesammelt durch die Brüder Grimm (t. 1 i 2). Berlin: Georg Reimer. (wyd. oryg. 1812-1815).

Grimm, W., Grimm, J. (1837). Die Kinder- und Hausmärchen. Gesammelt durch die Brüder Grimm (t. 1 i 2). Göttingen: Dieterich. (wyd. oryg. 1812-1815).

Grimm, W., Grimm, J. (1857). Die Kinder- und Hausmärchen. Gesammelt durch die Brüder Grimm (t. 1 i 2). Göttingen: Dieterich. (wyd. oryg. 1812-1815).

Grimm, W., Grimm, J. (1896). Bajki domowe i dziecinne zebrane przez braci Grimmów (Z. A. Kowerska, tłum., t. 1 i 2). Warszawa: Księgarnia M. Arcta. (wyd. oryg. 1857).

Grimm, W., Grimm, J. (1982). Baśnie braci Grimm (E. Bielicka, M. Tarnowski, tłum., t. 1 i 2). Warszawa: Ludowa Spółdzielnia Wydawnicza. (wyd. oryg. 1857).

Grimm, W., Grimm, J. (2010a). Baśnie dla dzieci i dla domu (E. Pieciul-Karmińska, tłum., t. 1 i 2). Poznań: Media Rodzina. (wyd. oryg. 1857).

Grimm, W., Grimm, J. (2010b). Diabeł i jego babcia. W: Baśnie dla dzieci i dla domu (E. Pieciul-Karmińska, tłum., t. 2, s. 150-155). Poznań: Media Rodzina. (wyd. oryg. 1857)

Grimm, W., Grimm, J. (2010c). Mądra Elżunia. W: Baśnie dla dzieci i dla domu (E. Pieciul-Karmińska, tłum., t. 1, s. 183-187). Poznań: Media Rodzina. (wyd. oryg. 1857).

Grimm, W., Grimm, J. (2010d). Pani Trude. W: Baśnie dla dzieci i dla domu (E. Pieciul-Karmińska, tłum., t. 1, s. 224-225). Poznań: Media Rodzina. (wyd. oryg. 1857).

Grimm, W., Grimm, J. (2010e). Stary Sułtan. W: Baśnie dla dzieci i dla domu (E. Pieciul-Karmińska, tłum., t. 1, s. 250-252). Poznań: Media Rodzina. (wyd. oryg. 1857).

Grimm, W., Grimm, J. (2019a, 1 kwietnia). Długi nos (tłum. E. Pieciul-Karmińska). Przekrój. Pobrane z: https://przekroj.pl/kultura/wysluzeni-zolnierze-dorotheaviehmann-i-opowiesci-z-karczmy. (wyd. oryg. 1815).

Grimm, W., Grimm, J. (2019b, 12 maja). Dziwaczna uczta (tłum. E. Pieciul-Karmińska). Przekrój. Pobrane z: https://przekroj.pl/kultura/dziwaczna-uczta-bracia-grimm. (wyd. oryg. 1812).

Grimm, W., Grimm, J. (2019c). Pan Szast-Prast (tłum. E. Pieciul-Karmińska). Czas Literatury, 5, 5-6.

Martus, S. (2013). Die Brüder Grimm. Eine Biographie. Reinbek bei Hamburg: Rowohlt.

Pieciul-Karmińska, E. (2013). Geneza baśni braci Grimm a ich przekład na język polski. W: S. Puppel, T. Tomaszkiewicz, Scripta manent - res novae (s. 105-115). Poznań: WN UAM.

Pieciul-Karmińska, E. (2016). O konieczności polskiego przekładu pierwszego wydania Baśni dla dzieci i dla domu braci Grimm z lat 1812 i 1815. Rocznik Przekładoznawczy, 11,77-92.

Pieciul-Karmińska, E. (2019a, 6 lutego). Bracia Grimm - historia nieznana. Przekrój. Pobrane z: https://przekroj.pl/kultura/bracia-grimm-historia-nieznana. 
Pieciul-Karmińska, E. (2019b, 12 maja). Malcia wysmarkaj się, czyli skąd się wzięła Dziwaczna uczta. Przekrój. Pobrane z: https:/przekroj.pl/kultura/malciawysmarkaj-sie-czyli-skad-sie-wziela-dziwaczna-uczta.

Pieciul-Karmińska, E. (2019c). Wachmistrz Krause i malarz Schindehütte. Czas Literatury, 5, 2-4.

Pieciul-Karmińska, E. (2019d, 1 kwietnia). Wysłużeni żołnierze, Dorothea Viehmann i opowieści z karczmy Knallhütte. Przekrój. Pobrane z: https://przekroj.pl/kultura/ wysluzeni-zolnierze-dorothea-viehmann-i-opowiesci-z-karczmy-2.

Rölleke, H. (1975). Die „Stockhessischen” Märchen der „Alten Marie”. Das Ende eines Mythos um die frühesten KHM-Aufzeichnungen der Brüder Grimm. Germanisch-Romanische Monatsschrift, 25, 74-86.

Rölleke, H. (1986). Kinder- und Hausmärchen. Gesammelt durch die Brüder Grimm. Transkription und Kommentare in Verbindung mit Ulrike Marquardt von Heinz Rölleke. Göttingen: Vandenhoeck \& Ruprecht.

Rölleke, H. (1998). Grimms Märchen und ihre Quellen. Die literarischen Vorlagen der Grimmschen Märchen synoptisch vorgestellt und kommentiert. Trier: Wissenschaftlicher Verlag.

Rölleke, H. (2004). Die Märchen der Brüder Grimm. Eine Einführung. Stuttgart: Reclam.

Rölleke, H. (2012). Die Beiträge der Dorothea Viehmann zu Grimms Kinder- und Hausmärchen. W: H. Ehrhardt (red.), Dorothea Viehmann (s. 30-45). Kassel: Euroregioverlag.

Rölleke, H., Schindehütte, A. (2011). Es war einmal... Die wahren Märchen der Brüder Grimm und wer sie ihnen erzählte. Frankfurt a. Main: Eichborn.

Schindehütte, A. (1991). Krauses Grimm'sche Märchen. Marburg: Hitzeroth.

Schindehütte, A. (1992). Das Spinnenstubenheft. Marburg: Hitzeroth.

Zipes, J. (2002). The brothers Grimm: From enchanted forests to the modern world.

New York, NY: Palgrave Macmillian. 